\title{
La Justicia como instancia simbolica y la reconstruccion del sujeto de derecho
}

\author{
Raúl Enrique $\mathscr{R}_{\text {ojo }}$
}

\section{Introducción ${ }^{2}$}

La democracia no consiste, al decir de MONTESQUIEU (1748: 245) «en obrar de tal manera que todo el mundo gobierne o que nadie obedezca, sino en obedecer y gobernar a sus iguales». El verdadero espíritu de igualdad, afirmaba el barón de La Brède, «no persigue el fin de los señoríos, sino tener a sus iguales por señores». La Justicia debe evitar, entonces, el riesgo de la democracia extrema, aquella donde gobernando «todo el mundo», nadie obedece. Y haciéndolo va en contra del air du temps, de aquel que parece ser el sentido en que marchan las democracias: la negación del mal, la evacuación de la política (de la cual sin embargo ellas proceden), y el cuestionamiento de toda jerarquía, fruto, creemos, de un sentimiento más

profundo aún: la negativa a pagar cualquier precio. Queremos unión sin matrimonio, sexo «seguro» y sin hijos, hijos que no lloren ni crezcan, adelgazar sin dieta, escuela sin control de asistencia y sin evaluación, cárcel sin barrotes, psiquiatría sin internación ${ }^{3}$, y riqueza, en fin, sin esfuerzo, trabajo o ahorro. ¡Si hasta las naciones pretenden hacer ahora la guerra sin muertos! Nunca nos gustó ver nuestras propias filas diezmadas, claro (aunque supiésemos que "quienes iban a matar también podían morir"), pero hoy tampoco se soporta que haya bajas entre las fuerzas o la población enemigas. Se pasa, así, de la "bomba de neutrones" de la guerra fría (que se suponía que podía matar a los humanos y dejar en pie a los edificios,

${ }^{1}$ Abogado por la Universidad de Buenos Aires (UBA); Magíster en Sociología por la Pontificia Universidad Católica Argentina "Santa María de los Buenos Aires" (UCA); Doctor en Sociología por la École des Hautes Études en Sciences Sociales (EHESS, París). Ex docente de la Universidad de Buenos Aires. Director de investigaciones del Centre de Recherches sur l'Administration de la Justice et la Société (CRAJS, París). Profesor e investigador concursado de la Universidad Federal de Río Grande do Sul (UFRGS, Porto Alegre). Programas de Posgrado en Sociología y de Posgrado en Derecho. E-Mail: raulrojo@vortex.ufrgs.br

${ }^{2}$ Estas reflexiones tuvieron su origen en las clases de "Temas de Sociología" dictadas por el autor en el Posgrado de Derecho de la Universidad Federal de Río Grande do Sul, durante los años lectivos de 2000 y 2001. En su actual redacción deben mucho a las observaciones y participación de los alumnos, aunque el autor debe ser tenido por el único responsable de los yerros que pueda contener el presente trabajo.

${ }^{3}$ La antipsiquiatría, movimiento que pretendía sacar los enfermos del asilo, tuvo por efecto externar un gran número de personas de entre las cuales algunas no eran capaces de vivir fuera. Y lo que afuera han encontrado no ha sido la libertad sino el encierro sin paredes, la soledad con su sufrimiento y sus síntomas. El movimiento iniciado por atendibles y humanas razones terapéuticas, ha sido continuado por razones presupuestarias, procurando ocultar la ineficiencia y el abandono de las instalaciones psiquiátricas, acabando por dejar sin ningún tratamiento a gran número de enfermos. 
puentes y fábricas) a los "bombardeos quirúrgicos" del nuevo orden internacional, donde se busca aniquilar los recursos materiales del oponente evitando matar a su gente. $O$ escamoteando, al menos, la imagen de sus muertos difundida por CNN. Al fin y al cabo, este "negarse a pagar" no es más que una manifestación de una tendencia cada vez más generalizada, que parece conducirnos hacia un brave new world, "políticamenre correcto" y soft, pasteurizado e infantilizado, de quesos asépticos, cigarrillos sin alquitrán y cerveza sin alcohol, suerte de "Disneyworld" con entrada franca y juegos "al alcance de todos los bolsillos".

En ese sentido, la Justicia parece una institución contra natura. Debe, al mismo tiempo, organizar la violencia contra la tolerancia democrática, asumir la distancia en una sociedad de proximidad, mantener las ficciones en un mundo escéptico, administrar las sanciones en colectividades anómicas, diferir el espectáculo para una platea constituida por espectadores "en directo", imponer la frustración en una sociedad de la seducción, declarar lo que es justo para un mundo desencantado y establecer referencias para un universo desorientado. Este distanciamiento interno que la Justicia impone a la democracia, es esencial, sin embargo, para cualquier tipo de reflexión. La Justicia detiene la lógica autodestructiva del individualismo para transformar al individuo en sujeto de derecho, pondera la alternativa entre el liberalismo salvaje y el dirigismo a través de la idea de personalización del derecho y morigera los ímpetus de los jueces. Hace justicia en una democracia secularizada, recuerda la norma compartida en una democracia pluralista, erige una

barrera simbólica en una democracia participativa y encarna la autoridad en una democracia representativa.

La autoridad debe mantener la distancia fundamental de la democracia a través de un trabajo que es simultáneamente de conformación y escenificación. Esta distancia es indispensable para mantener el aliento democrático. Si el poder se halla tentado constantemente de identificarse a sí mismo y emanciparse de toda referencia, si los media tienden inercialmente a una democracia directa liberándose de la mediación de las instituciones, y si la democracia individualista confunde el individuo con sus deseos y emociones, la Justicia se presenta como una instancia simbólica que se interpone entre lo real y su representación, entre el poder y sus orígenes, entre el individuo, el sujeto y el derecho. Antes que represiva o social, civil o penal, arbitral o tutelar, la Justicia, repetimos, es un instancia simbólica que debe establecer puntos de referencia colectivos ${ }^{4}$.

La Justicia es una "institución identificadora" del tipo de aquellas que Charles TAYLOR opone a las que también él denomina "instituciones servicio". "Por un lado - dice TAYLOR (1994: 93) - tenemos estructuras cuya relación con nuestras vidas es únicamente instrumental, aún cuando los servicios que nos prestan son muy importantes y, por otro, tenemos medios cuya frecuentación crea para nosotros un espacio elemental de definición de valores importantes, puntos de partida de polos posibles de identidad". La modernidad va convirtiendo las instituciones identificadoras en instituciones servicio y aquellas que conservan un fuerte valor identificatorio, como

${ }^{4}$ Ciertos criminales "de alto coturno" lo han advertido, ya, entre nosotros. Véase, sino, al sanguinario PINOCHET, que no se inmutó en su momento con la "caravana de la muerte" pero a quien desvela la posibilidad de ser prontuariado (es decir, identificado como un delincuente común, a través de los signos exteriores que la policía y la Justicia utilizan para tal fin), o nuestros delincuentes "de cuello blanco", que finalmente se entregan con la condición "de no ser esposados"...

Revista da Faculdade de Direito da UFRGS, v. 20, Outubro/2001 la religión o la cultura, están en vías de privatización o individuación. Tal es el riesgo que también corre la Justicia: la idea de un "servicio público de la justicia" es la tentación constante de aquellos que se alzan contra el supuesto "gobierno de los jueces". ¿Cómo resistir a esta tendencia? ¿Qué significa concretamente, para la Justicia, asumir el papel de institución identificadora? El Palacio de Justicia (el foro), aún cuando los tribunales estén vacíos, sigue identificando el lugar donde se hace justicia. La Justicia es identificadora, tanto para la sociedad al instaurar el debate como para el individuo restaurando la parte de sujeto de derecho que le es propia.

\section{Escena y jurisdicción}

La Justicia es una instancia, decíamos, un espacio que existe por sí mismo, cuya virtud es existir y que hace de esa misma existencia una virtud. La Justicia, a su turno, es indisociable de un espacio que permite a cada actor identificarse con su papel y, consecuentemente, con una escena en la cual el grupo social interpreta constantemente su papel, esto es: su destino. El parentesco entre la escena teatral y la escena moral es profunda: jurisdicción de la escena. Es por eso que la televisión se comporta, queriéndolo o no, como instancia moral. Cuando todas las otras instituciones sociales hayan desaparecido CHILLR - la escena continuará cumpliendo una función moral: "la jurisdicción de la escena comienza allí donde se detienen las leyes del mundo. (...) Osados criminales, que desde hace tiempo se pudren en la sombra o han sido reducidos a polvo, son convocados por el llamado todopoderoso de la poesía y vuelven a representar sus innobles papeles para la terrible edificación de la posteridad. Impotentes, cual imágenes furtivas de un espejo deformante, los horrores de cada siglo pasan ante nuestros ojos, mientras maldecimos su memoria con voluptuoso terror. Cuando no se enseñe más ninguna moral, cuando ninguna religión encuentre más fe, cuando ninguna ley tenga vigencia, Medea vendrá a aterrorizarnos, precipitándose desde las escalinatas del Palacio después de haber asesinado a sus hijos" (SCHILLER, 1784: 119-120). De allí la importancia de no desdeñar esta dimensión espectacular del oficio de juzgar que debe preocuparse de escenificar adecuadamente esta virtud. La democracia espera del legis lador que sea un buen régisseur del debate judicial, y de los jueces que sean buenos actores.

\subsection{Un universo hecho de distancia}

La representación no tiene "buena pren"en este siglo XXI aún balbuciante y ya tan amante de la "autenticidad". La exigencia de "no tener pelos en la lengua" es alimentada por los medios de comunicación masiva. La democracia no se cansa de desmontar los escenarios en los que cree ver una última desigualdad que debe combatir en estos momentos en que las jerarquías sociales tienden a desaparecer. Pero todo no pasa de una trampa: los lugares del juez y del acusado nunca serán intercambiables. El espacio judicial tiene que marcar su especificidad y guardar sus distancias, so pena de frustrar a esos voyeurs en que nos hemos convertido.

Los desbordes, de los que el siglo XX fue muestrario "problemático y febril" (al decir de Enrique Santos DISCÉPOLO) aconsejan esta prudencia. El despotismo adoptó en este siglo dos aspectos bien diferenciados y coexistentes: el de la politización del proceso y, al mismo tiempo, el de la interiorización extrema. "Exceso de representación" y "representación insuficiente" convivieron en él. Los sistemas totalitarios se apropiaron del espacio judicial, en el que organizaron procesos políticos donde la suerte estaba echada de antemano y el decorado había sido erigido para estimular una especie de 
unanimidad ritual ${ }^{5}$. Pero ésta no fue la única perversión de la Justicia. La justicia informal, es decir la que se lleva a cabo en la soledad de un despacho, al abrigo de las miradas del pueblo (que está en el origen de la competencia y la legitimidad del juez) elude igualmente el momento solemne de la justicia. Esta forma banal de hacer justicia destiló otra forma de despotismo menos visible y mucho menos cruenta, donde la dominación se escondió detrás del paternalismo estatal, abriendo el camino del control que denunció con tanto vigor Michel FOUCAULT (1975).

El espacio del proceso articula la relación entre "personas", es decir, etimológicamente, entre "máscaras". La ceremonia desapasiona las relaciones interpersonales y las transforma en relaciones de derecho. La escena imposta los sentimientos, protege al juez de la culpabilidad de juzgar, al testigo del temor de declarar y a la víctima de la vergüenza de serlo. La Justicia no sondea los corazones, así como no pretende corregir los comportamientos: su misión es restaurar el orden simbólico del derecho y consecuentemente establecer la distancia.

El mundo judicial es un mundo frío, solemne y alejado de la vida cotidiana. En él, la comunicación, significa algo muy distinto de lo que representa en el mundo de los media. Las partes están distantes del juez y deben dirigirse a él en público y en medio de un decorado impresionante. La comunicación del proceso es frustrante: todo en él es formal y, en consecuencia, sospechosamente artificial. La comunicación judicial parece en abierta

contradicción con la ideología actual que celebra los principios de la comunicación directa y la comunión afectiva. El carácter artificial de la audiencia es, sin embargo, condición necesaria para la verdad convencional de la democracia. Las formas del proceso son indisponibles en tanto puesta en escena del Otro, de la democracia, por una parte, y de marco para el debate, por la otra.

Ese espacio sin dueño de la sala de audiencias manifiesta la distancia fundamental que en él mantienen tanto el sujeto cuanto la comunidad política. La función política del espacio judicial consiste en instaurar una dis tancia entre lo privado y lo público, entre lo interno y lo externo, entre el sujeto de carne y hueso y el sujeto de derecho. Esta distancia entre los diferentes protagonistas del proceso significa la imposible fusión con el otro de mi propia carne, la prohibición del incesto que es, de alguna manera, la ley de leyes. La distancia que impone el ritual judicial demuestra que el lugar de la ley está vacío, que si en su entorno se organizan los intercambios sociales, él mismo permanece inaccesible para el común de los mortales. El Palacio de Justicia representa la exterioridad de la democracia, ese espacio sin dueño que el derecho se limita a señalar.

Esta metáfora espacial ha inspirado a numerosos pensadores de la democracia. "Al indicar cual es el espacio de la ley, el poder representa su papel de instituyente simbólico del campo social - dice Marcel GAUCHET (1976: 24). Pero sólo puede señalarlo eficazmente renunciando

${ }^{5}$ A título de mero ejemplo sirvan los harto conocidos procesos que en agosto de 1936, en enero de 1937, y del 2 al 13 de marzo de 1938, se entablaron contra los más eminentes bolcheviques de la "vieja guardia", antiguos compañeros de lucha de LENIN como ZINOVIEV, KAMENEV, RADEK, SOKOLNIKOF, BUJARIN, RYKOF, KRESTINSKI, YAGODA, RAKOVSKI, ROSENGOLZ, IVANOF, CHERNOF, GRINKO, etc. En estos prOSO fueron condenados a muerte los principales acusados (algunos de los cuales acabaron sus dís vivando procesos su verdugo). El 12 de junio de 1937 se produce la no menos famosa "purga" militar, que cuesta la vida a miLIN, TUJACHEVSKY y otros. Conf. la publicación oficial soviética, antisovietique, Moscú, Commisariat du Peuple de la Justice, 1938.

Revista da Faculdade de Direito da UFRGS, v. 20, Outubro/2001 ostensiblemente a ocuparlo". Por su parte, Claude LEFORT (1986: 27 y 29) agrega que, el carácter "revolucionario y sin precedentes" de la democracia reside en que, en ella, "el lugar del poder se convierte en un $l u$ gar vacio (...) Lo esencial es que se impide a los gobernantes apropiarse e incorporarse el poder. (...) La democracia se instituye y se mantiene en la disolución de las referencias de la certidumbre. Ella inaugura una historia en la que los hombres se hacen cargo de una indeterminación definitiva, en cuanto a los fundamentos del Poder, de la Ley y del Saber." El Estado de derecho debe renunciar constantemente a la tentación de acortar esta distancia y hacer el duelo de su omnipotencia. En este sentido, el ritual judicial podría ser mucho más auténtico que la comunicación (supuestamente espontánea) que proponen los medios de comunicación de masas, que pretenden abolir la distancia esencial a toda democracia.

Esta separación entre la escena y la sala de audiencias reproduce la distinción entre lo público y lo privado, la diferencia entre coerción física y la libertad de conciencia. Las relaciones jurídico-procesales son exteriores y convencionales: pretender otorgarles mayor verismo puede constituir una amenaza a las libertades. Consecuentemente, cuanto más fuertes y simbólicamente consistentes sean las fronteras de este espacio, más favorecerán éstas a la representación dentro de la escena y a la libertad fuera de ella.

\subsection{Un metalenguaje evocador}

Quienquiera que entre por primera vez en un Palacio de Justicia se sorprenderá (por poco que el mismo haya sido construido en el siglo XIX o en la primera mitad del XX) con su aspecto de templo greco-romano. $\mathrm{Y}$ una vez en su interior atraerá su atención la profusión de símbolos tales como la espada y la balanza, las tablas de la ley, las inscripciones latinas y las alegorías frecuentemente pintadas en los techos abovedados o en las paredes de salas y corredores gélidos. ¿A qué se debe esta "densidad semiótica"? Todos estos símbolos son otras tantas referencias a los tiempos fundadores de nuestra civilización. Comenzando por la Biblia, en la cual se funda nuestra moral judeocristiana, siguiendo por Grecia, que liberó la razón de su ganga religiosa y acabando con Roma que creó el derecho tal como lo conocemos hoy en día. La imagen de la balanza es, por su parte, más vieja aún: se-remonta al antiguo Egipto y al pesaje de la almas. El Tribunal es también el lugar donde nos cruzamos con las efigies de los grandes legisladores: Justiniano y Cicerón, Tejedor y Dalmacio Vélez Sarsfield, Teixeira de Freitas o Clovis Bevilacqua (guardando las debidas distancias). O de reyes-magistrados como San Luis, que encontramos haciendo justicia bajo su roble legendario en la galería de la Corte de Casación del Palacio de Justicia de París.

Nuestros tribunales están también llenos de imágenes pavorosas: la Medusa, por ejemplo, con su cabellera de serpientes y llorando lágrimas de sangre. En la mitología griega, la Medusa transformaba en piedra a quienes se atrevían a mirarla. Esas figuras nos invitan a desviar la mirada. $\mathrm{O}$, mejor aún, las miradas, en verdad, se invierten: es menos lo que reparamos en estos símbolos que lo que ellos nos marcan. Los hombres deliberan bajo la mirada de los padres y los mitos fundadores que les recuerdan los juramentos iniciales.

Los edificios parlamentarios y judiciales que levantamos hasta hace poco están, entonces, llenos de bustos de grandes legistas y de imágenes atemorizantes, de emblemas nacionales y de frescos históricos que recuerdan el largo camino que hubo que transitar para establecer las libertades democráticas (como en la rotonda de la Corte Suprema de los Estados Unidos o, en un sentido diametralmente 
opuesto pero perfectamente comparable, en el Polyforum Cultural de la Ciudad de México) ${ }^{6}$. Ningún espacio colectivo es concebible sin una cultura que le brinde una expresión simbólica propia, que exprese sus valores en un lenguaje de óleo, estuco, piedra y bronce.

El edificio de nuestros foros contribuía a instituir la autoridad de los jueces, entendida como capacidad de dar forma - material, simbólica e intelectualmente - a la pública deliberación. La autoridad es la fuerza del poder instituyente. La autoridad compensa el carácter evasivo del poder. "El poder es volátil, quienes lo hacen duradero son sus fundaciones [sus cimientos] como la acción es más frágil que la obra, el poder que deriva de ella precisa siempre ser incrementado por algo equivalente a la experiencia romana de la fundación", dice Paul RICOEUR (1993: 40). Esa es la función del ritual judicial: movilizar los símbolos de la Justicia cuantas veces se demande su intervención. La autoridad no es otra cosa que "la energía subsistente del acto fundante, la energía de los comienzos", acrecienta RICOEUR. Tal es el sentido de la repetición, propio de todo rito: repite incansablemente el momento fundador del proceso y reinicia este trabajo sin pausa de distanciamiento de la venganza privada y de la violencia ilegítima.

Estos símbolos, aparentemente obsoletos, son la clave de la modernidad: recordando nuestras tradiciones superadas por la aventura democrática, nos permiten avanzar. El marco es

lo que hace las veces de tradición para nuestros contemporáneos. La cultura compartida se vuelve evasiva a medida que nuestras sociedades se diversifican y se hacen más complejas y fragmentadas. El recurso al momento fundante es más necesario y vital cuanto más grande es el pluralismo. Un pluralismo sin referencias a una autoridad es tan ilusorio como una expansión de los derechos subjetivos carente de la contrapartida de sus obligaciones. Cuanto más una sociedad innova y se independiza de sus tradiciones, más necesidad tiene de evocar el momento fundador. La sociedad democrática substituye la tradición con una abstracción: el contrato social. Ahora bien, ¿cómo dar consistencia simbólica a esta realidad descarnada?

Los palacios de justicia actuales son mudos: nada los distingue de otros edificios públicos. Ese silencio arquitectural es peligroso. Los tribunales deberían continuar siendo, en la democracia del mañana, escenas, templos y foros. Nuestras sociedades que, según se dice, buscan denodadamente un sentido para sus actos, deben comenzar a encontrarlo en esos edificios que albergan sus deliberaciones cotidianas, es decir su perpetua gestación. A falta de tradiciones, el arquitecto moderno no sabe que oponer al vacío democrático. Para los individuos desorientados, el Palacio de Justicia debería ser una referencia, un lugar pedagógico: tendría que remitirlo tanto a un pasado inaccesible, como mostrarle el momento

${ }^{6}$ En el interior de la cúpula del Polyforum cultural de México, David Alfaro SIQUEIROS pintó una "escultopintura" de dos mil cuatrocientos metros cuadrados que tituló "La marcha de la humanidad sobre la tierra y hacia pina" dos des el cosmos". Desde la plataforma giratoria situada bajo la cúpula, se ve, a la izquierda, la marcha de la humanidad desde los tiempos de la esclavitud y de la superstición hasta la revolución democrático-burguesa, a pesar de los obstáculos que le oponen los señores, los demagogos y los militaristas. La segunda parte de la obra describe la marcha hacia la revolución futura a través de la violencia. La tercera describe la nueva vida en la que desemboca esta marcha secular: la ciencia y la técnica permiten la industrialización. Las manos de una mujer vierten, sobre esta sociedad liberada por el trabajo, las semillas de la paz y la armonía que la humanizan. En fin, en el centro de la cúpula, el hombre y la mujer, unidos en la paz y el amor, simbolizan este porvenir radiante. La obra es grandiosa y sin embargo, su mensaje pasaría desapercibido para los visitantes, si éstos no fueran advertidos del simbolismo por un oportuno folleto del que hemos extraído los párrafos precedentes.

Revista da Faculdade de Direito da UFRGS, v. 20, Outubro/200 indisponible de la vida en sociedad, allí donde se detiene la libertad individual.

1.3 La ritualización de la violencia domesticada

El paseante desprevenido puede igualmente quedar atónito con las representaciones violentas incluidas en la decoración de los viejos tribunales: impresionantes fauces abiertas de león, armas afiladas, cuerpos humanos heridos de muerte. Este cruel simbolismo sorprende: se podría imaginar que en un lugar como ese sería mejor apaciguar a las personas, alentar la reconciliación por imágenes pacíficas o inspirar la concordia.

Es que la violencia aquí no es negada sino, por el contrario, exhibida y sublimada. Estas imágenes de las que apenas tomamos conciencia cumplen sin duda un papel compensatorio. Esas escenas vengadoras y terribles, los colmillos del león, las hachas afiladas y las aguzadas lanzas no sólo nos inspiran respeto sino que nos liberan de nuestra agresividad, para restituirnosla de forma simbólica. Estas representaciones crueles, sádicas a veces, nos dispensan de serlo a nuestro turno, descargan nuestras pulsiones ocultas ofreciendo el espectáculo, atemorizante pero liberador, de la violencia. Atestiguan el parentesco del proceso con el sacrificio. La falta de autoridad se paga con un aumento de la violencia, con la reaparición de una lógica expiatoria, como lo demuestra la evolución de la violencia en la sociedad democrática.

A diferencia de la violencia que entra todos los días en nuestras casas vehiculizada por los medios de comunicación masiva, el ritual judicial muestra al mismo tiempo el espectáculo de la transgresión y el de su reabsorción. Procura, así, un sentido para la violencia y le propone un alivio legítimo. En otras palabras, la violencia no es exhibida en do. Las reacciones que suscita esta violencia son canalizadas, diríamos, por el derecho y e procedimiento. El proceso es una suerte de procedimiento. El proceso es una suerión de la violencia por el rito. En la audiencia el crimen no es negado sino repetido en un universo simbólico que desmonta la violencia. El crimen es reconstituido por la palabra: todos los protagonistas (testigos, peritos, policías) son convocados e invitados a exponer lo que ha ocurrido. El proceso judicial es una conmemoración del crimen a través de la palabra y el procedimiento. Anula la violencia salvaje por una violencia eufemística, que se impone al acusado. Esta violencia catártica es posible únicamente gracias al efecto de disimulación producido por el ritual. Este espectáculo de violencia mediatizado por la palabra se encuentra indisolublemente vinculado al espectáculo de reabsorción de la violencia. En los medios de comunicación, en cambio, la violencia es generalmente ofrecida en estado puro, cruel, absurda, comprendiéndose las reacciones emotivas e incontroladas que genera. Con mayor razón cuando la falta de canales de desahogo clásicos de las pasiones democráticas (como las luchas patrióticas, políticas o sindicales) no hace más que acrecentar el interés por las violencias del derecho común. A la sociedad democrática le resulta cada vez más difícil asumir sus pasiones, a medida que la emoción pública es cada vez menos simbolizable.

\subsection{La mediación institucional del debate}

El espacio de la Justicia es un lugar específico, propio (cosa que no alcanzan a comprender los media, en particular la televisión, que igualan todos niveles). La institución de un lugar de deliberación hace que éste no se confunda ni con el espacio más pequeño de la negociación o la terapia, ni con el más vasto de espacio público. El Estado debe garantizar el buen funcionamiento de la Justicia en un espacio protegido, delimitado en el interior del 
espacio público? .

Normalmente, el común de las gentes no se detiene a pensar sobre este exorcismo de la violencia colectiva, ni sobre la memoria viva de la tradición que contiene el marco ritual de proceso, pero los perciben. El marco es, en efecto, fundamentalmente percepción: su acción no es inmediatamente inteligible por los individuos. Está presente, se trata de un universo simbólico que, en sí mismo, es una representación del universo, un espacio que alberga el desenvolvimiento de la instancia. E lenguaje, en cambio, es linear: permite encadenar de manera lógica los argumentos y excluir los diferentes sentidos posibles para conducir a una solución. Contrasta, en esto, con el símbolo que es polisémico por definición. El marco, al contrario, permanece inmóvil, repetitivo: insensible a los regímenes políticos, al tiempo y a la historia. No evoluciona, es un no-suceso indispensable para que un suceso - el proceso - se produzca. El marco otorga a los argumentos una situación, los enraíza en la historia.

Así, por sus vínculos con la tradición y por su simbolización de la violencia, el marco ritual no oprime sino que libera a la razón. Permite combinar razón y tradición, lo irracional de la violencia con una elaboración racional. El intercambio regulado de argumentos no es más que la "parte viva" del proceso que necesita de un "espacio protegido". Quienes limitan la Justicia a un mero debate olvidan que los curiales no se encuentran levitando en un vacío social sino que también son sujetos de pasiones. No hay juicio - y el jurídico menos que cualquier otro - que no se produzca en situación tributario de un lenguaje y de un marco específicos. El símbolo vincula el texto y el contexto. Marco simbólico y debate corren juntos, como tradición y argumentación o como autoridad y poder. El dispositivo ritual combina el espacio indisponible de autoridad y el espacio abierto de la discusión. KAFKA nos ofrece la prueba por el absurdo. En El proceso, lo sagrado omnipresente aunque impalpable - oprime e impide cualquier comunicación. Ningún hablar racional es posible, ningún intercambio. $\mathrm{El}$ trabajo de "distanciamiento mental a través de imágenes" es inviable. Joseph K. no llega a controlar esas imágenes que acaban por devorarlo. Sucumbe por orden de una autoridad ausente y

La autoridad de un marco simbólico identificable, de una mediación institucional, es indispensable para el ejercicio de todo poder, comenzando por el poder argumentativo. E marco simbólico niega las relaciones de fuerza y las diferencias sociales, autoriza un debate racional, expurga la violencia y celebra, más allá del conflicto, la continuidad de un destino colectivo y de la paz. El pacto democrático fundador es, de esta forma, "incrementado" por las instituciones.

\section{El sujeto de derecho}

Mientras la Justicia no fue más que el relevo del poder, la religión o las costumbres, su función simbólica era poco significativa. Este papel permanece latente en una sociedad saturada de sentido como la sociedad tradicional, en la que la Justicia se limita a apaciguar los cruel cuya ley ha sido extraviada.

${ }^{7}$ La Justicia se parece a la escuela, en este aspecto como en muchos otros derivados de su carácter compartido de "instituciones identificadoras". La escuela republicana, en efecto, también debe ser un lugar cerrado (a contracorriente de quienes hoy en día la exigen "abierta a la vida"), cerrado detrás de sus muros y de sus propios reglamentos, sin los que perdería su independencia (sinónimo de laicismo) respecto de las fuerzas sociales, políticas, económicas o religiosas que se la disputan.

Revista da Faculdade de Direito da UFRGS, v. 20, Outubro/2001 conflictos. Una función de autoridad más autónoma en una democracia privada de sentido exige - y esta es una de las originalidades de la Justicia actual - que ella asuma mejor su papel de instancia simbólica. Cuando la Justicia debe asumir el papel de autoridad by default, su función simbólica es mucho más significativa. Si la sociedad democrática corre peligro de falencia simbólica, debe reactivarse ese pape identificador, tanto en lo tocante al espacio público como al sujeto de derecho.

Para comprender la noción de sujeto de derecho puede resultar interesante reinsertar la misma en una perspectiva histórica. Todo sistema de justicia descansa implícitamente sobre una representación del delito o del desorden social, de la persona y de la manera de hacerle frente. Varias representaciones del sujeto de derecho se han así sucedido a lo largo de la historia.

\subsection{El modelo expiatorio}

Los cuerpos de normas de las primeras décadas del siglo $\mathrm{XX}$, como e Código Penal que todavía rige a los argentinos, por ejemplo, se representan la infracción como un mal uso del "libre arbitrio", como un cálculo que era necesario hacer no rentable (porque "el crimen no paga"). La delincuencia es percibida en ellos como un acto, sea éste la expresión de una voluntad sana que ha mostrado una falla, un desvío en el trayecto que debía haberse seguido, o bien como el resultado de una voluntad descarriada que persiste en el mal, de la misma manera que los viejos jumentos insisten en seguir el mismo camino para retornar al pesebre.

Como no conoce otra solución que la exclusión por el castigo, este primer modelo ha sido calificado de expiatorio. No se exige a la Justicia que tome en cuenta la sutileza de las relaciones afectivas o la injusticia de las situaciones sociales. La Justicia tiene aquí una función esencialmente punitiva: debe excluir al productor de desórdenes, tanto en materia penal como civil. Así el juez del divorcio expulsa del domicilio conyugal al cónyuge culpable y le retira la guarda de los hijos, el juez de menores interna en un asilo (lo más lejos posible de su hogar) al menor maltratado, y el juez penal encarcela al delincuente o lo envía a cumplir trabajos forzados en tierras lejanas. El condenado es pura y simplemente excluido: el mejor ejemplo de ello lo constituye la incapacidad relativa de derecho, es decir la supresión de los derechos políticos y civiles que acompaña a los condenados a largas penas privativas de libertad.

Se trata de un derecho sumamente "puro": sin contaminación con otro conocimientos como los de las ciencias sociales. Las categorías de este derecho son claras: el problema es civil o penal, el delincuente o es un loco o una persona absolutamente responsable. No puede haber en él graduaciones de responsabilidad, ni transición entre la libertad total y el encarcelamiento.

Se supone que todo el mundo goza de la misma capacidad social, y ahí está e problema. Este sistema formalista sólo garantizaba derechos, en verdad, a a un número limitạdo de personas: los hombres, mayores, propietarios, católicos y casados legítimamente. Los otros no estaban sino parcialmente - cuando no absolutamente privados de la capacidad propia de los sujetos de derecho. El derecho positivo necesita perentoriamente de un modelo social que haga las veces de referente. El legislador, igual que los jueces, los abogados, los psiquiatras y los asistentes sociales se referían implícitamente a este modelo decimonónico. Por eso el derrumbe simbólico de ese modelo social dominante 
perturbó todo el equilibrio del derecho. 2.2 El modelo terapéutico

Esta dialéctica del crimen y el castigo fue progresivamente sustituida por la de síntoma y el tratamiento, con arreglo a la cual el delincuente comienza a ser visto más como un enfermo que como un perverso. En este segundo modelo se impone la lógica de la curación: por eso se lo puede llamar terapéutico. La delincuencia aparece no ya como una voluntad desviada sino como la manifestación de una personalidad desequilibrada.

Es a esta época que se remonta la percepción psicologizante del sujeto. La resocialización es el primer objetivo y a él se consagra la Justicia, corriendo el riesgo de abandonar la idea de responsabilidad jurídica si ella no parece corresponder a la realidad de las cosas. Para esta concepción extremadamente subjetiva del sujeto de derecho, hay que procurar la responsabilidad en el propio sujeto bajo la forma de culpabilidad. Durante un buen tiempo imperó, así, un concepto determinista de delincuente, que aún no hemos abandonado del todo.

\subsection{El modelo cívico}

¿A qué representación del sujeto podemos vincular nuestro naciente siglo XXI? Por cierto que ni a aquella ficción de la persona absolutamente libre, social y económicament autónoma, a ese burgués del siglo XIX, ni a ese otro individuo estructuralmente determinado, desapropiado de cualquier tipo de soberaní sobre sí mismo que el siglo XX nos dejó como legado. No: a nuestra época debe corresponder un sujeto capaz. Nuestro siglo descubre que la capacidad no es un hecho que podría ser observado. Es un poder que un agente piens poder ejercer, o que los otros le encomiendan desempeñar.
Este tercer modelo - que llamaremos civico - supone que el sujeto no puede se reducido ni a sus determinismos, ni a sus deseos. Procede de una distancia interior de una relación a sí mismo. La perspectiva de una sumisión a las leyes que nos hemos dado a nosotros mismos supone, en efecto, la referencia a sí como posibilidad real y distinta a lo que hay en nosotros de súbdito (y de sumisión a un gobernante, aún benevolente) El ideal humanista de autonomía requiere en nosotros la definición de una parte de humanidad compartida, irreductible a la firmación de nuestra mera singularidad, y a la cual nuestra singularidad debe someterse.

¿Qué es, en definitiva, un sujeto de derecho? Una persona autónoma, capaz en e sentido jurídico del término, es decir: la única habilitada para definir sus intereses $y$, consecuentemente, el exclusivo emisor de una palabra propia. No se puede limitar el sujeto a una suma de reivindicaciones unilaterales. $\mathrm{E}$ sujeto de derecho debe ser definido como sujeto de palabra $y$ de escucha, como autónomo $y$ dependiente, como depositario de una dignidad inalienable $y$ susceptible de ser momentáneamente enervada.

\subsection{El ciudadano como sujeto de derecho}

Nuestra época parece haber descubierto el valor rehabilitante de obligación como medio de reinsertar y, al mismo tiempo, de pagar la deuda social, de os deberes como la otra cara social de los derechos. Todo no es posible, aquí, sino a condición de que el sujeto de derecho sea reconocido como sujeto de palabra, y es por eso que la Justicia tiene consecuencias la intimación a explicarse, así como la facultad de asumir compromisos (de la que el juez es garante), brindan la posibilidad de modificar el curso de la institución por una palabra suficientemente trascendente.
El sujeto de derecho es indivisible, es decir que no puede perder su calidad de tal sin perder su dignidad. El sujeto de derecho es la versión judicial del ciudadano, no vinculado a una nacionalidad sino a su exclusiva condición humana.

El modelo cívico permite eludir la alternativa sujeto/no-sujeto, persona reputada acabadamente libre y sana de espíritu, al contrario, condenada a la locura y la muerte civil. Cada uno debe verse reconocida una igual e inalienable dignidad en tanto que hombre, cualquiera sea su situación social o mental. El límite de sujeto no pasa más entre ciertos sujetos para separarlos de otros ciudadanos que tendrían derechos, sino que atraviesa e interior de cada sujeto para definir un um bral infranqueable que permitirá considerar con más pragmatismo su situación concre ta. La idea de un individuo acabadamente asimilado a su deseo se fragmenta en dos: una, que da cuenta de la calidad de sujeto de derecho, depositario de una irreductible dignidad que no se puede perder jamás, y otra, que toma en consideración a un ser singular que puede estar en crisis o momentáneamente disminuido. La acción de las instituciones tendrá por material la situación, y por objetivo la dignidad. Estos dos estados del sujeto de derecho introducen una tensión en la Justicia. El reconocimiento de este límite fijado por la dignidad, más allá del cual no será posible avanzar, permite tomar en consideración situaciones concretas que el modelo expiatorio ignoraba deliberadamente, pero también sin extraviarse en ellas como en el modelo terapéutico. El regreso a la plena capacidad del sujeto de derecho proporciona a la acción social su horizonte teórico, con arreglo al cual toda crisis es considerada, en principio, como pasajera.
Se restablece, así, una distancia en el propio interior del individuo (por la introducción de dos polos: la dignidad compartida y la situación concreta) que no podía aparecer mientras se mantuviera la confusión, en una sola persona, del sujeto jurídico y del individuo psicológico. Como dice Denis SALAS (1992: 90), "el derecho penal debería decir al individuo que su personalidad no es lo mismo que su individualidad, que ella le brinda un estatus social y cívico que va más allá de su persona privada, y que se refiere a aquella parte de él mismo que es acreedora y deudora respecto de la sociedad".

\section{Conclusiones}

El juez aparece exigido por diversos imperativos contradictorios: aplicar e derecho y reparar la ofensa cometida al orden público, pero de manera inteligente $y$, sobre todo, eficaz. De allí el desafío que constituye, para una sociedad desacralizada y un individuo desorientado, la preservación de un momento de autoridad, es decir, de mantenimiento simultáneo de la violencia legítima y de la dimensión simbólica. Tal tipo de confrontación con la dimensión colectiva de la vida social es indispensable para la reconstrucción del sujeto. Reconstruir el sujeto de derecho es un objetivo político y no apenas humanista o caritativo - de la Justicia. Entre sujeto de derecho y Estado de derecho existe, en efecto, una especie de circularidad. El sujeto de derecho no es únicamente una condición de la intervención social, sino que constituye también su principal objetivo.

Ser ciudadano significa tener la posibilidad de asociarse realmente a la gestión de la vida pública; ser súbdito de un Estado de 
derecho implica simplemente poder defender sus intereses antes de que una decisión sea tomada. La diferencia entre un súbdito que tiene ciertos derechos y el ciudadano radica en que este último está en el origen del poder de sus mandatarios. Los ciudadanos, en el sentido político del término, detentan la soberanía original, lo que significa que los funcionarios (de los tres poderes) deben obtener (directa indirectamente) de ellos su investidura y rendirles cuenta de su gestión. Los sujetos de derecho, a diferencia de los súbditos de un dés-

\section{Referências Bibliográficas}

FOUCAULT, M. 1975. Surveiller et punir naissance de la prision. París, Gallimard.

GAUCHET, M. 1976. «L'expérience totalitaire et la pensée du politique», Esprit, 7-8, pp. 3-21.

LEFORT, C. 1986. Essais sur le politique (XIX ${ }^{e}$ - XX $X^{e}$ siècles). París, Éditions du Seuil.

MONTESQUIEU (Ch. L. de Secondat, barón de La Brède y de). 1748. De l'Esprit des lois. La cita del texto, traducida por el autor del trabajo, ha sido extraída de la ed. Garnier/ Flammarion, París, 1979.

RICOEUR, P. 1993. «Le juste entre le légal et bon», in: Lectures 1, París, Éditions du Seuil.

SALAS, D. 1992. «État et droit pénal. Le droit pénal entre 'Thémis' et 'Dikè'», Droits, 15.

SCHILLER, F. von. 1784. La scène considérée comme institution morale. La cita del texto, traducida por el autor del trabajo, ha sido extraída de Justice et théâtre, París, Éditions Quintette, 1991.

TAYLOR, C. 1994. «Les institutions dans la vie nationale», Esprit, 200, pp. 90-102. pota ilustrado, son a la vez seres dotados de derechos y coautores del derecho. Tener derechos es tener, ante todo, el derecho de participar del debate sobre el derecho, de ser, uno mismo, autor (directa e indirectamente) de su propio derecho. Restituir al individuo (dominado, determinado, sometido a la presión de la exclusión social) su dignidad de sujeto de derecho, despertar en él la parte de soberanía que le pertenece, tal es el objetivo de la intervención judicial. Y con ese alcance la reivindicamos. 